\title{
Beryllium-7 Aerosols in Ambient Air
}

\section{Constantin Papastefanou*}

Atomic and Nuclear Physics Laboratory, Aristotle University of Thessaloniki, Thessaloniki 54124, Greece

\begin{abstract}
The aerodynamic size distribution of ${ }^{7} \mathrm{Be}$ aerosol particles in ambient air was determined by using 1-ACFM and high-volume (HVI) cascade impactors, $20 \mathrm{~m}$ above the ground on the roof of the Faculty of Science building, Aristotle University of Thessaloniki at Thessaloniki Greece $\left(40^{\circ} 38^{\prime} \mathrm{N}\right.$, $22^{\circ} 58^{\prime} \mathrm{E}$ ) from November 2006 to June 2008. The activity concentration of ${ }^{7} \mathrm{Be}$ aerosols was determined by gamma spectrometry $(\mathrm{E} \gamma=0.477 \mathrm{MeV})$. The activity size distribution of ${ }^{7} \mathrm{Be}$-aerosols was largely associated with submicron aerosol particles in the accumulation mode $(0.4-2.0 \mu \mathrm{m})$. The activity median aerodynamic diameter, AMAD varied from 0.76-1.18 $\mu \mathrm{m}$ (average $0.90 \mu \mathrm{m}$ ), indicating post-condensation growth either in the upper atmosphere or after mixing into the boundary layer. The geometric standard deviation, $\sigma_{\mathrm{g}}$ varied from 1.86-2.77 (average 2.24). The activity size distribution of ${ }^{7} \mathrm{Be}$-aerosols peaked in the $0.7-1.1 \mu \mathrm{m}$ size range in the $65 \%$ of the measurements carried out by the 1-ACFM cascade impactor. In estimating lifetimes of ${ }^{7}$ Be-aerosols in ambient air, a mean residence time of about 8 days averaged for atmospheric aerosols of $0.90 \mu \mathrm{m}$ AMAD size.
\end{abstract}

Keywords: Beryllium-7; Radioactive aerosols; Aerosol impactors; 1-ACFM; AMAD; Residence time.

\section{INTRODUCTION}

Beryllium-7 is a relatively short-lived $\left(\mathrm{T}_{1 / 2}\right.$ $=53.3$ days, $\tau=1 / \lambda=77$ days) naturally occurring radionuclide of cosmogenic origin which is formed by spallation processes of light atmospheric nuclei, such as carbon $(\mathrm{Z}=$ $6)$, nitrogen $(Z=7)$ and oxygen $(Z=8)$, when

\footnotetext{
* Corresponding author. Tel.: +30-2310-998005;

Fax: +30-2310-998058

E-mail address: papastefanou@physics.auth.gr
}

the above nuclei absorb protons and even neutrons of the primary component of cosmic rays, according to the following reactions:

$$
\begin{aligned}
& { }_{6}^{12} \mathrm{C}+{ }_{1}^{1} \mathrm{p} \rightarrow{ }_{4}^{7} \mathrm{Be}+{ }_{2}^{6} \mathrm{Li} \quad{ }_{7}^{14} \mathrm{~N}+{ }_{1}^{1} \mathrm{p} \rightarrow{ }_{4}^{7} \mathrm{Be}+2{ }_{2}^{4} \mathrm{He} \quad{ }_{8}^{16} \mathrm{O}+{ }_{1}^{1} \mathrm{p} \rightarrow{ }_{4}^{7} \mathrm{Be}+{ }_{5}^{10} \mathrm{~B} \\
& \longrightarrow{ }_{4}^{7} \mathrm{Be}+{ }_{3}^{7} \mathrm{Li}+{ }_{2}^{3} \mathrm{He} \\
& { }_{6}^{12} \mathrm{C}+{ }_{0}^{1} \mathrm{n} \rightarrow{ }_{4}^{7} \mathrm{Be}+{ }_{2}^{6} \mathrm{He} \quad{ }_{7}^{14} \mathrm{~N}+\mathrm{n}_{0}^{1} \mathrm{n} \rightarrow{ }_{4}^{7} \mathrm{Be}+{ }_{3}^{8} \mathrm{Li} \quad{ }_{8}^{16} \mathrm{O}+{ }_{0}^{1} \mathrm{n} \rightarrow{ }_{4}^{7} \mathrm{Be}+{ }_{4}^{10} \mathrm{Be} \\
& \hookrightarrow{ }_{4}^{7} \mathrm{Be}+{ }_{2}^{6} \mathrm{He}+{ }_{2}^{4} \mathrm{He}
\end{aligned}
$$

Essentially, the ${ }^{7} \mathrm{Be}$ atoms are produced by high-energy spallation interactions. Production 
is greatest in the upper stratosphere, but some energetic cosmic-ray neutrons and protons survive in the lower atmosphere, producing cosmogenetic radionuclides, such as ${ }^{7} \mathrm{Be}$. Production is not only altitude- but also latitude-dependent and varies as well with the 11-year solar cycle that modulates cosmic-ray penetration through the earth's magnetic field. The calculated global average production rate of cosmogenic ${ }^{7} \mathrm{Be}$ per unit surface area of the earth is 810 atoms $/ \mathrm{m}^{2} / \mathrm{s}$ and the average concentration of ${ }^{7} \mathrm{Be}$ in the troposphere is $\mathbf{1 2 . 5}$ $\mathrm{mBq} / \mathrm{m}^{3}$ (UNSCEAR 2000).

Once ${ }^{7} \mathrm{Be}$ is formed in the troposphere, it rapidly associates primarily with submicronsized aerosol particles (Bondietti et al., 1984; 1987). Beryllium-7 in these fine aerosols may subsequently enter the marine as well as the terrestrial environment and vegetation via wet or dry depositional events. Following deposition, ${ }^{7} \mathrm{Be}$ will tend to associate with particulate material (particle-reactive element).

Beryllium-7 has come to be recognized as a potential tool in studying the description of environmental processes, such as aerosol transit and residence times in the troposphere (Martell 1970), aerosol deposition velocities (Young and Silker 1980) and aerosol trapping by above ground vegetation (Bondietti et al., 1984).

Beryllium-7, and other natural radionuclides like ${ }^{22} \mathrm{Na},{ }^{32} \mathrm{P},{ }^{33} \mathrm{P},{ }^{35} \mathrm{~S}$ and ${ }^{210} \mathrm{~Pb}$, participate in the formation and growth of the accumulation mode aerosols (0.07-2 $\mu \mathrm{m}$ diameter) which is a major reservoir of pollutants in the atmosphere (Bondietti et al., 1987). Following its production by gas-phase nuclear transformation, this isotope condenses on the aerosol population, growing by condensation of non-radioactive species e.g. sulfates or organic (McMurry and Wilson, 1982; 1983) and so the fate of ${ }^{7} \mathrm{Be}$ will become the fate of the carrier aerosols (Bondietti et al., 1984; 1987). On the behavior of ${ }^{7} \mathrm{Be}$ atoms with atmospheric aerosols, it was concluded from early aerosol studies that considerable coagulation occurred during migration of ${ }^{7} \mathrm{Be}$ atoms from the stratosphere and upper troposphere to ground level air (Friedlander, 2000; Grundel and Porstendörfer, 2004; Grundel et al., 2005).

This paper summarizes results of an investigation designed to characterize the aerodynamic size distributions and the aging of atmospheric aerosols in the context of ${ }^{7} \mathrm{Be}$ distributions for better understanding of aerosol growth mechanisms and the behaviour of radioactive aerosols in the atmosphere.

\section{EXPERIMENTAL PROCEDURE}

The aerodynamic size distribution of ${ }^{7} \mathrm{Be}$ in atmospheric aerosols was achieved by using Andersen 1-ACFM cascade impactors. This 1ACFM impactor involves a flow rate of 1.7 $\mathrm{m}^{3} / \mathrm{h}\left(28.3 \mathrm{~L} / \mathrm{min}\right.$ or $\left.1 \mathrm{ft}^{3} / \mathrm{min}\right)$ and eight atmospheric pressure stages for collecting aerosols above $0.4 \mu \mathrm{m}$ (Fig. 1). The effective cutoff diameters (ECDs) of this impactor were as follows: $0.4,0.7,1.1,2.1,3.3,4.7,5.8$ and $9.0 \mu \mathrm{m}$. The stainless steel plates supplied by the manufacturer were used for aerosol collection. Glass fiber filters were used as back up filters to collect particles below the 


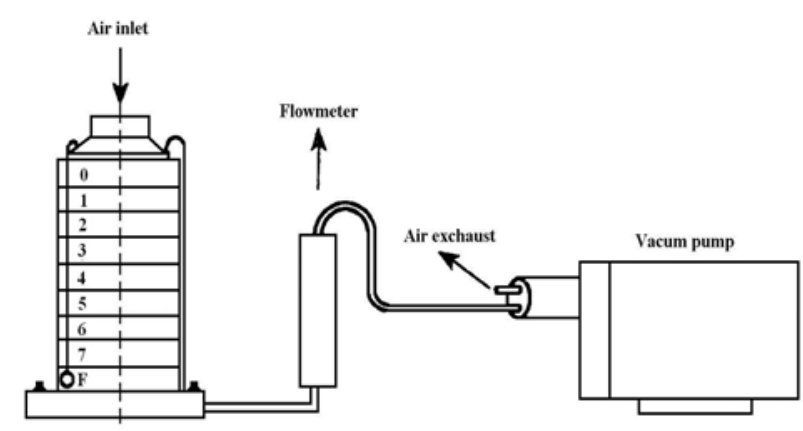

Fig. 1. A schematic diagram of an 1-ACFM cascade impactor complete system.

$0.4 \mu \mathrm{m}$ collection plate. Polycarbonate films can also be used as back up filters.

The length of each collection period was 1 week. The samples were collected $20 \mathrm{~m}$ above the ground on the roof of the Faculty of Science building, Aristotle University of Thessaloniki, Greece $\left(40^{\circ} 38^{\prime} \mathrm{N}, 22^{\circ} 58^{\prime} \mathrm{E}\right)$.

The stainless steel collection plates of the impactor as well as the back up filters used as plane radioactive sources were measured for ${ }^{7}$ Be activity $\left(\mathrm{E}_{\gamma}=0.477 \mathrm{MeV}\right)$ by gamma-ray spectrometry using a high resolution $(1.9 \mathrm{keV}$ at $1.33 \mathrm{MeV}{ }^{60} \mathrm{Co}$ ), high efficiency (42\%), low-background high purity Ge coaxial-type detector. Uncertainty in counting of ${ }^{7} \mathrm{Be}$ activity was varied from $10-20 \%$. Less than 3 mg of particulate material on any impactor stage was collected in each sampling, thus overloading ( $\geq 10 \mathrm{mg}$ on any stage) was excluded. A typical gamma-ray spectrum of a glass fiber air filter obtained by a Ge detector, in which the $0.477 \mathrm{MeV} \gamma$-ray peak of ${ }^{7} \mathrm{Be}$ is clearly shown in Fig. 2.

High-volume cascade impactors, HVI can also be used for the size fractionation of atmospheric aerosol particles. These impactors have a regular air-flow rate either of $0.57 \mathrm{~m}^{3} / \mathrm{min}(20 \mathrm{cfm})$ or $1.13 \mathrm{~m}^{3} / \mathrm{min}(40 \mathrm{cfm})$ and the effective cutoff diameters (ECDs) are $0.41,0.73,1.4,2.1,4.2$ and $10.2 \mu \mathrm{m}$ for the 20 cfm configuration or $0.49,0.95,1.5,3.0$ and $7.2 \mu \mathrm{m}$ for the $40 \mathrm{cfm}$ configuration at the standard temperature and pressure

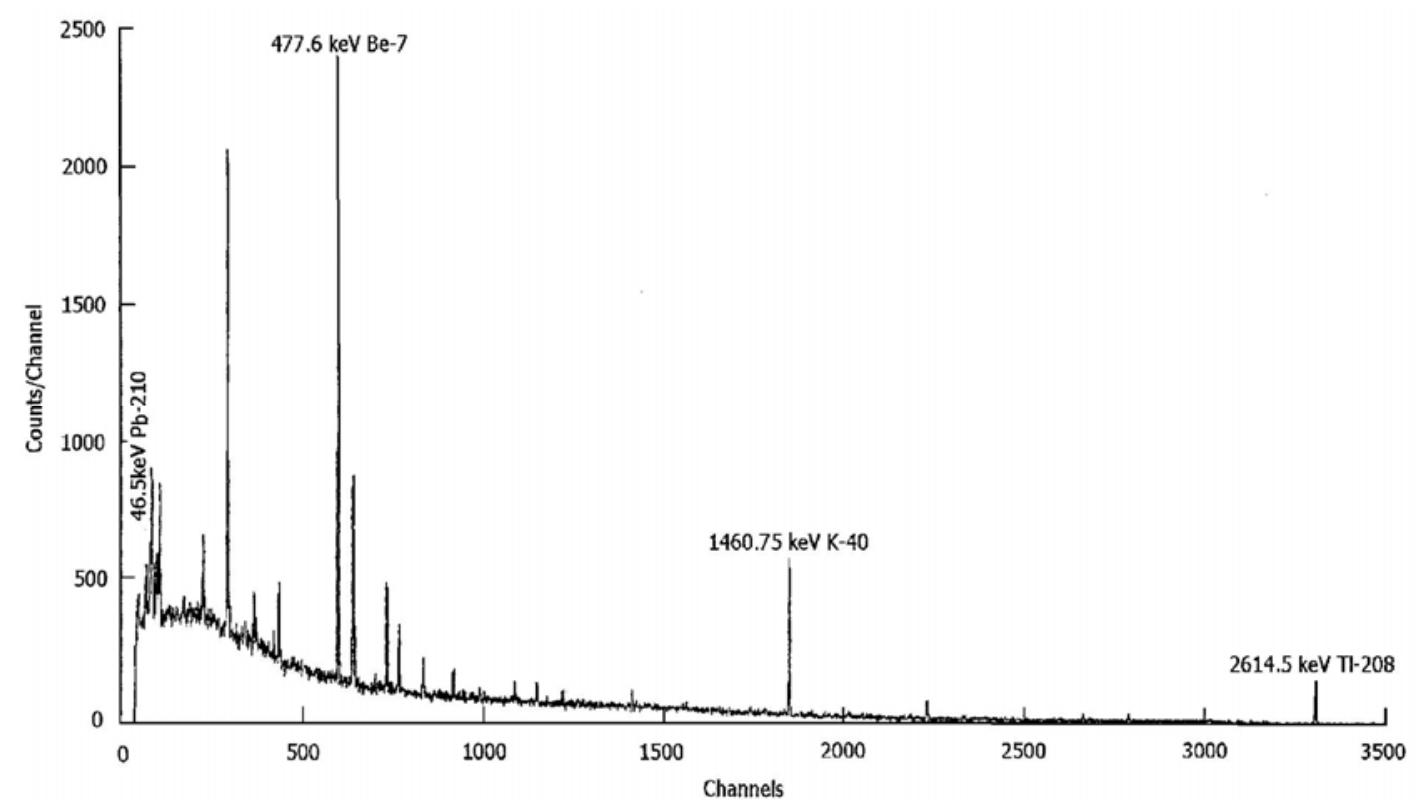

Fig. 2. Plot of a $\gamma$-ray spectrum of an atmospheric aerosol sample (air filter) obtained by a Ge detector. 
atmospheric conditions $\left(25^{\circ} \mathrm{C}\right.$ and $760 \mathrm{~mm}$ $\mathrm{Hg}$ ).

\section{RESULTS AND DISCUSSION}

\section{Beryllium-7 Aerosol Size Distribution}

A typical plot of the activity size distribution of ${ }^{7} \mathrm{Be}$ versus aerodynamic diameter $\left(D_{p}\right)$ is represented in Fig. 3 This distribution was selected from 11 measurements (samplings) made over an almost 2-y period.

Atmospheric aerosol size distribution appears to follow a trimodal distribution expected for condensation-derived aerosols. This trimodal distribution of atmospheric aerosols is showing the following modes: (i) the Aitken nuclei mode which ranges from 0.003-0.07 $\mu \mathrm{m}$ (average $0.015 \mu \mathrm{m}$ ), (ii) the accumulation mode which ranges from 0.07-2 $\mu \mathrm{m}$ (average $0.3 \mu \mathrm{m}$ ) and (iii) the coarse mode which ranges from 2-36 $\mu \mathrm{m}$ (average $>10 \mu \mathrm{m}$ ) (NRC 1979). Young et al. (1975) reported that ${ }^{7} \mathrm{Be}$ is attached primarily to submicron-sized

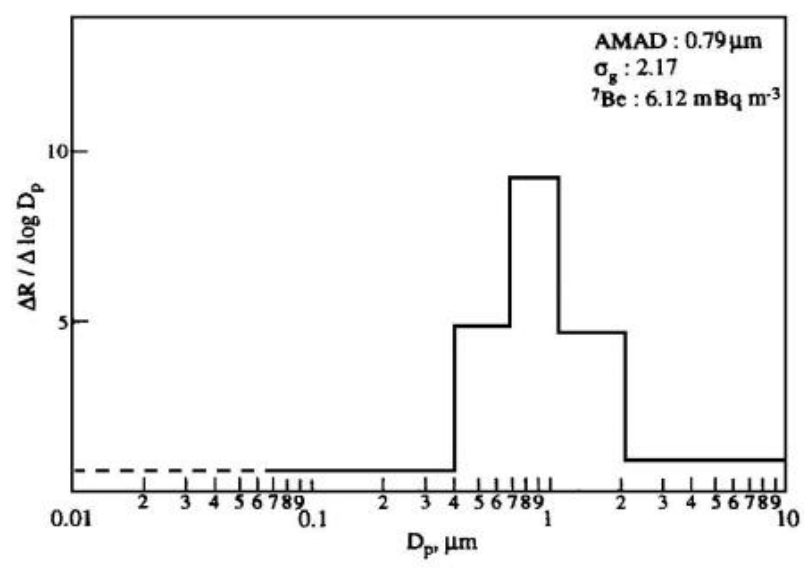

Fig. 3. Aerodynamic size distribution of ${ }^{7} \mathrm{Be}$ ambient aerosols. particles in the atmosphere. About $88 \%$ of ${ }^{7} \mathrm{Be}$ was found to be present on particles smaller than $1.1 \mu \mathrm{m}$ in diameter, and less than $1 \%$ was on particles larger than $7 \mu \mathrm{m}$ in diameter. That means, ${ }^{7} \mathrm{Be}$-aerosols are accumulation mode aerosols. It is also evident from the plot of Fig. 3.

From eleven measurements carried out in a 2-y period at Thessaloniki, Greece with a temperate latitude $\left(40^{\circ} 38^{\prime} \mathrm{N}, \quad 22^{\circ} 58^{\prime} \mathrm{E}\right)$ precipitation-free (dry) climate, the activity median aerodynamic diameter (AMAD) varied from 0.76-1.18 $\mu \mathrm{m}$ (average $0.90 \mu \mathrm{m}$ ) and the geometric standard deviation $\left(\sigma_{\mathrm{g}}\right)$ varied from 1.86-2.77 (average 2.24). The AMAD and $\sigma_{\mathrm{g}}$ calculations were made by plotting the cumulative distributions on lognormal probability paper. It was shown that $69 \%$ of the ${ }^{7} \mathrm{Be}$ activity was associated with aerosol particles with diameter smaller than $1.1 \mu \mathrm{m}$.

Table 1 shows data for the activity median aerodynamic diameter, AMAD of atmospheric aerosol particles associated with ${ }^{7} \mathrm{Be}$ atoms. The AMAD values for ${ }^{7} \mathrm{Be}$-aerosols reported from the literature varied from 0.33-1.15 $\mu \mathrm{m}$ with the upper values being pretty close to the upper value of this work.

From a different view of the obtained results, the ${ }^{7} \mathrm{Be}$ activity size distribution dominated in smaller size range of aerosol particles with AMAD $0.68 \mu \mathrm{m}\left(\sigma_{\mathrm{g}}=2.18\right)$ at height $250 \mathrm{~m}$, and $0.62 \mu \mathrm{m}\left(\sigma_{\mathrm{g}}=2.24\right)$ at height $1000 \mathrm{~m}$, showing a dependency on height. In marine environment, the ${ }^{7} \mathrm{Be}$ activity size distribution dominated to higher size range of aerosol particles with AMAD 
Table 1. Activity median aerodynamic diameters (AMADs) of ${ }^{7}$ Be-aerosols.

\begin{tabular}{lll}
\hline${ }^{7}$ Be AMADs $(\mu \mathrm{m})$ & Latitude & Reference \\
\hline $0.76-1.18$ (avg. 0.90) & $40^{\circ} 38^{\prime} \mathrm{N}$ & This work \\
$0.29-0.50$ (avg. 0.35) & $35^{\circ} 58^{\prime} \mathrm{N}$ & Bondietti et al. (1987) \\
$0.65-1.09$ (avg. 0.77) & $51^{\circ} 32^{\prime} \mathrm{N}$ & Reineking and Porstendorfer (1995) \\
$0.44-0.74$ (avg. 0.57) & $48^{\circ} 13^{\prime} \mathrm{N}$ & Winklet et al. (1998) \\
$1.12-2.06$ & $54^{\circ} 41^{\prime} \mathrm{N}$ & Lujaniene et al. (2001) \\
$0.33-1.15$ (avg. 0.67) & $22^{\circ} 18^{\prime} \mathrm{N}$ & Yu and Lee (2002) \\
0.70 & $51^{\circ} 32^{\prime} \mathrm{N}$ & Grundel and Porstendorfer $(2004)$ \\
0.53 & $28^{\circ} 04^{\prime} \mathrm{N}$ & Mohamed (2005) \\
\hline
\end{tabular}

$0.82 \mu \mathrm{m}\left(\sigma_{\mathrm{g}}=1.88\right)$.

Bondietti et al. (1987) in thirteen measurements in an almost one-year period at Oak Ridge, Tennessee with temperate latitude $\left(35^{\circ} 58^{\prime} \mathrm{N}, 84^{\circ} 30^{\prime} \mathrm{W}\right)$ and wet climate showed that the activity median aerodynamic diameter, AMAD varied from 0.29-0.50 $\mu \mathrm{m}$ (average $0.35 \mu \mathrm{m})$ and that the fraction of ${ }^{7} \mathrm{Be}$ associated aerosols above $1.4 \mu \mathrm{m}$ was usually between 5 and $10 \%$, i.e. analytically, $4.5 \%$ was found in the 1.4-2.1 $\mu \mathrm{m}$ size range, $1.1 \%$ in the 2.1-4.2 $\mu \mathrm{m}$ size range, and only $0.2 \%$ in sizes greater than $4.2 \mu \mathrm{m}$. They also concluded that cosmogenic radionuclides, such as ${ }^{7} \mathrm{Be}$ and ${ }^{35} \mathrm{~S}$ were associated with smaller aerosols in respect of the longer-lived radionuclides, such as ${ }^{210} \mathrm{~Pb}$, a decay product of ${ }^{222} \mathrm{Rn}$, of terrestrial origin, which were associated with larger-sized aerosols.

Röbig et al. (1980) reported that the distribution of ${ }^{7} \mathrm{Be}$ is shifted to larger particle sizes due to large residence time of ${ }^{7} \mathrm{Be}$ in the atmosphere. An equivalent aerodynamic diameter about $0.65 \mu \mathrm{m}$ for ${ }^{7} \mathrm{Be}$ might be resulted from the plot of the activity size distribution of the ambient air obtained by a high volume cascade impactor (flow rate 68 $\left.\mathrm{m}^{3} / \mathrm{h}\right)$ at Göttingen, Germany $\left(51^{\circ} 32^{\prime} \mathrm{N}\right.$, $\left.9^{\circ} 55^{\prime} \mathrm{E}\right)$. Shifts to large particle sizes were also observed when the relative humidity increased during rainfalls. Very recently, Grundel and Porstendörfer (2004) observed that the results of the ${ }^{7} \mathrm{Be}$ measurements for a period of four weeks carried out in outdoor air of a suburb area of the town of Göttingen showed no activity fraction in the nucleation (Aitken nuclei) mode, but a small amount of the activity $(5 \%)$ in the coarse mode size range (Fig. 4). The accumulation mode of ${ }^{7} \mathrm{Be}-$ aerosols with an activity fraction of $95 \%$ has an $\mathrm{AMAD}_{\mathrm{a}}$-value of $702 \mathrm{~nm}$. The activity size distribution of ${ }^{7} \mathrm{Be}$-aerosols depends probably on the location of formation. Most of ${ }^{7} \mathrm{Be}$ atoms and the ${ }^{7} \mathrm{Be}$-aerosols is generated in the upper region of the atmosphere, where other aerosol conditions exist than in the lower atmosphere. Earlier, Reineking and Porstendörfer (1995) by using a Berner-type cascade impactor in an one-year period at Göttingen, Germany, reported AMAD values for the ${ }^{7} \mathrm{Be}$-aerosols in the outdoor atmosphere varying between 650 and $1094 \mathrm{~nm}$ (average 


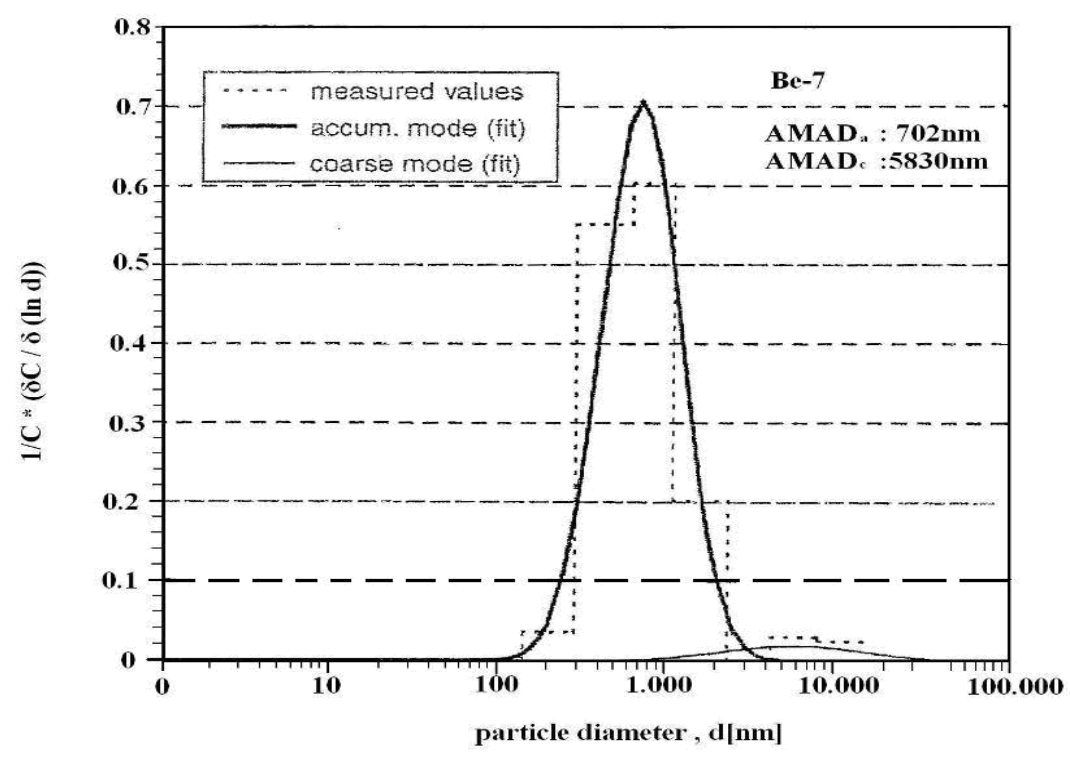

Fig. 4. Relative activity size distribution of ${ }^{7} \mathrm{Be}$ in outdoor air (Grundel and Porstendorfer, 2004).

$767 \mathrm{~nm})$ and the geometric standard deviation, $\sigma_{\mathrm{g}}$ varied between 1.8 and 2.5 (average 2.1), and that the increase of the AMAD values of ${ }^{7} \mathrm{Be}$-aerosols can in respect of radon decay product aerosols be explained by coagulation processes and the average residence times of about 17-22 days.

Winkler et al. (1998) in forty six measurements in a period of $11 / 3$ years at Munich-Neuherberg, Germany $\left(48^{\circ} 13^{\prime} \mathrm{N}\right.$, $\left.11^{\circ} 36^{\prime} \mathrm{E}\right)$ at a semi-rural area, $490 \mathrm{~m}$ above sea level showed that the AMAD of ${ }^{7} \mathrm{Be}$-aerosols ranged from $0.44-0.74 \mu \mathrm{m}$ (average $0.57 \mu \mathrm{m}$ ) and that seasonal effect during the period of high ${ }^{7} \mathrm{Be}$ air concentrations, i.e. in the summer, relatively low values of the AMAD (0.45-0.52 $\mu \mathrm{m})$ have been observed. They also concluded that the activity median aerodynamic diameter, AMAD ranged between the mass median aerodynamic diameter, MMAD and the surface median aerodynamic diameter, SMAD of the ambient aerosols, indicating that this radionuclide is involved in the transformation process of the tropospheric aerosols after formation in the stratosphere and upper troposphere.

$\mathrm{Yu}$ and Lee (2002) in fourteen measurements at Hong Kong $\left(22^{\circ} 18^{\prime} \mathrm{N}\right.$, $114^{\circ} 10^{\prime \prime} \mathrm{E}$ ) for a $3 \frac{1}{2}-$-month period resulted that the activity median aerodynamic diameter of ${ }^{7}$ Be-aerosols varied from 0.33-1.15 $\mu \mathrm{m}$ (average $0.67 \mu \mathrm{m}$ ). They oncluded that the AMAD of ${ }^{7} \mathrm{Be}$-aerosols is anticorrelated to ${ }^{7} \mathrm{Be}$ concentrations in air, is correlated to relative humidity, $\mathrm{RH}$ and the mean cloud cover, while temperature does not affect the AMAD of ${ }^{7}$ Be-aerosols.

Mohamed (2005) very recently by using a low-pressure Berner-type cascade impactor at El-Minia, Egypt $\left(28^{\circ} 04^{\prime} \mathrm{N}, 30^{\circ} 45^{\prime} \mathrm{E}\right)$ found an average AMAD value of ${ }^{7} \mathrm{Be}$-aerosols in outdoor air $530 \mathrm{~nm}$ with relative geometric standard deviation $\sigma_{\mathrm{g}}=2.4$ and that ${ }^{7} \mathrm{Be}$ as a gas diffuses more effectively to a smaller surface area of smaller particles because of the higher surface of these particles. 
Apart of this, Lujaniene et al. (2001) reported larger ${ }^{7}$ Be AMAD values varied from 1.12-2.06 $\mu \mathrm{m}$ (average $1.45 \mu \mathrm{m}$ ) in a northern latitude $\left(54^{\circ} 41^{\prime} \mathrm{N}, \quad 25^{\circ} 19^{\prime} \mathrm{E}\right)$ at Vilnius, Lithuania.

The investigated data (Table 1) rather indicate that the activity median aerodynamic diameter, AMAD of ${ }^{7} \mathrm{Be}$-aerosols increase with increasing latitude (latitudinal effect). As cosmic radiation increases with latitude, the number of ${ }^{7} \mathrm{Be}$ atoms and ions formed increase also with latitude, and so there are more ${ }^{7} \mathrm{Be}$ atoms available either to form small aerosol particles in the nucleation (Aitken nuclei) mode and then growing or to be attached directly to the existing large particles in the accumulation mode or in the coarse particle mode by increasing the AMAD of ${ }^{7} \mathrm{Be}$ aerosols.

\section{Residence Times of ${ }^{7} \mathrm{Be}$ Atmospheric}

\section{Aerosols}

The method for estimating the residence time of atmospheric aerosol particles associated with the radioactive nuclides, such as ${ }^{7} \mathrm{Be}$ of cosmogenic origin, is based on the aerosol particle growth rate.

Assuming that the resulting aerosols growth rate (the change in particle diameter, $\mathrm{D}_{\mathrm{p}}$ with respect to time ) ranged from 0.004-0.005 $\mu \mathrm{m} / \mathrm{h}$ as might be derived from the best fit for droplet phase reactions for the accumulation mode aerosols according to the theory of secondary ambient aerosol growth by condensation and coagulation (McMurry and Wilson, 1982; 1983), then, the residence time, $\tau_{\mathrm{R}}$ of the aerosol can be calculated by dividing the difference between the mean activity median aerodynamic diameter (AMAD) mean that is of $0.90 \mu \mathrm{m}$ for ${ }^{7} \mathrm{Be}$-aerosols (Table 1) and the mean size of Aitken nuclei particles, that is $0.015 \mu \mathrm{m}$ (NRC 1979), by the mean particle growth rate, MGR according to the equation

$\tau_{\mathrm{R}}=\frac{(\mathrm{AMAD})_{\text {mean }}-(\mathrm{AMAD})_{\text {Aitken }}}{\mathrm{MGR}}$

where MGR is the mean growth rate $(0.004-$ $0.005 \mu \mathrm{m} / \mathrm{h})($ McMurry and Wilson, 1982).

Taking into account that the AMAD of aerosol particles associated with ${ }^{7} \mathrm{Be}$ varied from $0.76-1.18 \mu \mathrm{m}$ (Table 1), then according to the Eq. (2) the residence time of atmospheric aerosols will vary between 7.4 and 8.9 days (average 8.0 days) at Thessaloniki region $\left(40^{\circ} 38^{\prime} \mathrm{N}, 22^{\circ} 58^{\prime} \mathrm{E}\right)$, Northern Greece, with dry (precipitation-free) climate at temperate latitude, based in twelve measurements of aerosol samplings carried out during 1 1 $\frac{1}{2}$-year period, thus included all seasons of a year.

Papastefanou and Bondietti (1991) reported mean residence times of 8 days for atmospheric aerosols in the boundary layer as determined from ${ }^{210} \mathrm{Bi} /{ }^{210} \mathrm{~Pb}$ activity ratios at Oak Ridge, Tennessee with temperate latitude $\left(35^{\circ} 58^{\prime} \mathrm{N}, 84^{\circ} 30^{\prime} \mathrm{W}\right)$ and wet climate. Therefore, in an attempt to estimate tropospheric aerosol residence times for cosmic-ray spallation products, such as ${ }^{7} \mathrm{Be}$, longer residence times for tropospheric air can be attributed to the influence of stratospheric aerosol contributions as the residence times of 
about one week are considered to be valid for tropospheric aerosols at all level of the troposphere (Martell and Moore, 1974).

Table 2 shows data for the residence times, $\tau_{R}$ of atmospheric aerosol particles associate with ${ }^{7} \mathrm{Be}$ atoms. The reported from the literature $\tau_{\mathrm{R}}$ values for ${ }^{7} \mathrm{Be}$-aerosols varied from 2.6-35.4 days.

Winkler et al. (1998) estimated residence times 5-6 days in forty six measurements for ${ }^{7} \mathrm{Be}$-aerosol samplings carried out during $1 \frac{1}{3} 3^{-}$ year period in ground level air at a semi-rural area at Neuherberg, Germany $\left(48^{\circ} 13, \mathrm{~N}\right.$, $\left.11^{\circ} 36, \mathrm{E}\right), 490 \mathrm{~m}$ above sea level.

Shapiro and Forbes-Resha (1976), much earlier estimated a mean residence tropospheric aerosol residence time for ${ }^{7} \mathrm{Be}$ bearing aerosols of 35.4 days, significantly higher, i.e. more than four times higher, at Fullerton, California $\left(33^{\circ} 52^{\prime} \mathrm{N}, 117^{\circ} 55^{\prime} \mathrm{W}\right)$, also at mid-latitude for an almost 2-year period with relatively light precipitation.

Yu and Lee (2002) recently estimated mean residence times for ${ }^{7} \mathrm{Be}$-associated aerosols ranging from 2.6-11.8 days in fourteen measurements of aerosol samplings carried out during a 31/2-month period (November-March), $20 \mathrm{~m}$ above ground at Hong Kong, China $\left(22^{\circ} 18^{\prime} \mathrm{N}, 114^{\circ} 10^{\prime} \mathrm{E}\right)$ including winter and spring measurements.

Balkanski et al. (1993) following a global three-dimensional model which uses meteorological parameters, such as precipitation scavenging, found that the tropospheric residence time is a function of latitude (latitudinal effect) according to the following equation (Ehhalt, 1973).
$\tau_{\mathrm{R}}=\mathrm{C} / \Phi$

where $\mathrm{C}$ is the tropospheric column of a radionuclide extending from the surface up to the model layer just below the tropopause, and $\Phi$ is the total depositional flux out of the column at a given latitude.

Koch et al. (1996) following a threedimensional chemical tracer model as Balklanski et al. (1993) also found that the tropospheric residence time is a function of latitude according to Eq. (3)

The data of Table 2 admit residence times of tropospheric aerosols in the range 2.6-35.4 days, but crowd into two groups of values 2.615 days (average 8.8 days) and 21-35.4 days (average 28.2 days). The lower values are applicable only to the boundary layer near Earth's surface and the higher values are appropriate to the troposphere as a whole (Junge, 1963). Martell and Moore (1974) came to the opposite conclusion, namely, that the high values are due to the contribution of stratospheric aerosols, while the lower values represent the true tropospheric residence time essentially independent of altitude.

\section{CONCLUSIONS}

The aerodynamic size distribution of ${ }^{7} \mathrm{Be}$ aerosols in ambient air were measured using normal (1-ACFM) and/or high-volume (HVI) cascade impactors. Beryllium-7 was largely associated with submicron aerosol particles in the accumulation mode (0.4-2.0 $\mu \mathrm{m})$. Based on eleven measurements of aerosol samplings, the activity median aerodynamic diameter, 
Table 2. Residence times, $\tau_{\mathrm{R}}$ of tropospheric aerosols.

\begin{tabular}{lll}
\hline Investigation & $\tau_{\mathrm{R}}$ (days) & Reference \\
\hline Thessaloniki, Greece $\left(40^{\circ} 38^{\prime} \mathrm{N}, 2^{\circ} 58^{\prime} \mathrm{E}\right)$ & $7.4-8.9($ avg. 8.0) & This work \\
Neuherberg, Germany $\left(48^{\circ} 13^{\prime} \mathrm{N}, 11^{\circ} 36^{\prime} \mathrm{E}\right)$ & 5.6 & Winkler et al. (1998) \\
Fullerton, California $\left(33^{\circ} 52^{\prime} \mathrm{N}, 117^{\circ} 55^{\prime} \mathrm{W}\right)$ & 35.4 & Shapiro and Forbes-Resha (1976) \\
Hong Kong, China $\left(22^{\circ} 18^{\prime} \mathrm{N}, 114^{\circ} 10^{\prime} \mathrm{E}\right)$ & $2.6-11.8$ & Yu and lee (2002) \\
\hline
\end{tabular}

AMAD of ${ }^{7} \mathrm{Be}$-aerosols ranged from 0.76 $1.18 \mu \mathrm{m}$ with a mean value of $0.90 \mu \mathrm{m}$, indicating post-condensation growth either in the upper atmosphere or after mixing into the boundary layer. In the $65 \%$ of the 1 -ACFM cascade impactor measurements the activity size distribution of ${ }^{7} \mathrm{Be}$-aerosols showed maxima in the 0.7-1.1 $\mu \mathrm{m}$ size range. The investigated data rather indicate that the activity size distribution of ${ }^{7} \mathrm{Be}$-aerosols increase with increasing latitude (latitudinal effect). Estimated lifetimes of ${ }^{7} \mathrm{Be}$-aerosols in ambient air resulted in a mean residence time of about 8 days that could be applied to aerosol particles in the lower atmosphere below the boundary layer. Contribution of stratospheric aerosols by intrusions could lead to higher values of residence time of atmospheric aerosols, as the residence times of stratospheric aerosols are of a month or higher (Martell, 1970; NRC, 1979; Friedlander, 2000).

\section{NOMENCLATURE}

1-ACFM Normal flow rate cascade impactor

$A M A D$ Activity median aerodynamic diameter

C Tropospheric column of a radionuclide
Cfm Cubic feet per meter

$D_{p} \quad$ Particle diameter

ECD Effective cutoff diameter

HVI High volume cascade impactor

MGR Mean particle growth rate

$M M A D$ Mass median aerodynamic diameter

$S M A D$ Surface median aerodynamic diameter

$T_{1 / 2} \quad$ Radioisotope half-life

Z Atomic number

\section{GREEK SYMBOLS}

$\lambda$ Radioisotope disintegration rate

$\sigma_{\mathrm{g}} \quad$ Geometric standard deviation

$\tau \quad$ Radioisotope mean life

$\tau_{\mathrm{R}} \quad$ Residence time of aerosol particles

$\Phi \quad$ Total depositional flux

\section{REFERENCES}

Balkanski, P.J., Jacob, D.J., Gardner, G.M., Graustein, W.C. and Turekian, K.K. (1993). Transport and Residence Times of Tropospheric Aerosols Inferred from a Global Three-Dimensional Simulation of ${ }^{210} \mathrm{~Pb}$. J. Geophys. Res. 98: 20573-20586.

Bondietti, E.A., Hoffmann, F.O. and Larsen, I.L. (1984). Air-to-vegetation Transfer Rates of Natural Submicron Aerosols. J. 
Environ. Radioact. 1: 5-27.

Bondietti, E.A., Papastefanou, C. and Rangarajan, C. (1987). Aerodynamic Size Association of Natural Radioactivity with Ambient Aerosols. Radon and its Decay Products: Occurrence, Properties and Health Effects, ACS Symposium Series 331, ed. P.K. Hopke, p. 377-397, American Chemical Society, Washington, DC.

Ehhalt, D.H. (1973). Turnover Times of ${ }^{137} \mathrm{Cs}$ and HTO in the Troposphere and Removal Rates of Natural Particles and Water Vapor. J. Geophys. Res. 78: 7076-7086.

Friedlander, S.K. (2000). Smoke, Dust and Haze: Fundamentals of Aerosol Dynamics. $2^{\text {nd }}$ ed. Oxford University Press, New York. Grundel, M. and Porstendörfer, J. (2004). Differences between the Activity Size Distributions of the Different Natural Radionuclide Aerosols in Outdoor Air. Atmos. Environ. 38: 3723-3728.

Grundel, M., Reineking, A. and Porstendörfer, J. (2005). Activity Size Distribution in Outdoor Air: Short-lived $\left.{ }^{(214} \mathrm{Po},{ }^{214} \mathrm{Bi} /{ }^{214} \mathrm{Po}\right)$ and Long-lived $\left({ }^{210} \mathrm{~Pb},{ }^{210} \mathrm{Po}\right)$ Radon and Thoron $\left({ }^{212} \mathrm{~Pb},{ }^{212} \mathrm{Po}\right)$ Decay Products and ${ }^{7} \mathrm{Be}$. Radioactivity in the Environment, edt. J.P.Mc Laughlin, S.E. Simopoulos and F. Steinhausler, p. 454-458, Elsevier, Amsterdam.

Junge, C.E. (1963). Air Chemistry and Radioactivity. Academic Press, New York.

Koch, D.M., Jacob, D.J. and Graustein, W.C. (1996). Vertical Transport of Tropospheric Aerosols as Indicated by ${ }^{7} \mathrm{Be}$ and ${ }^{210} \mathrm{~Pb}$ in a Chemical Tracer Model. J. Geophys. Res. 101: 18651-18666.
Lujaniene, G. Ogorodnikov, A. and Budyka, A.K. (2001). Size Distribution and Chemical Associations of Cosmogenic and Artificial Radionuclides in Ambient Aerosol. J. Aerosol Sci. 32: 535-536.

Martell, E.A. (1970). Transport Patterns and Residence Times for Atmospheric Trace Constituents vs. Altitude. Radionuclides in the Environment, Advanced Chemical Series 93, p. 138-157, American Chemical Society, Washington, DC.

Martell, E.A. and Moore, H.E. (1974). Tropospheric Aerosol Residence Times: A Critical Review. J. Rech. Atmos. 8: 903-910. McMurry, P.H. and Wilson, J.C. (1982). Growth Laws for the Formation of Secondary Ambient Aerosols: Implications for Chemical Conversion Mechanisms. Atmos. Environ. 16: 121-134.

McMurry, P.H. and Wilson, J.C. (1983). Droplet Phase (heterogeneous) and Gas Phase (homogeneous) Contributions to Secondary Ambient Aerosol Formation as Functions of Relative Humidity. J. Geophys. Res. 88: 5101-5108.

Mohamed, A. (2005). Activity Size Distributions of Some Naturally Occurring Radionuclides ${ }^{7} \mathrm{Be},{ }^{40} \mathrm{~K}$ and ${ }^{212} \mathrm{~Pb}$ in Indoor and Outdoor Environments. Appl. Radiat. Isot. 62: 751-757.

NRC (1979). Airborne Particles. National Research of Council. University Park Press, Baltimore.

Papastefanou, C. and Bondietti, E.A. (1991). Mean Residence Times of Atmospheric Aerosols in the Boundary Layer as Determined from ${ }^{210} \mathrm{Bi} /{ }^{210} \mathrm{~Pb}$ Activity Ratios. 
J. Aerosol Sci. 22: 927-931.

Reineking, A. and Porstendörfer, J. (1995). Time Variations of Size Distributions of Aerosol-attached Activities of ${ }^{212} \mathrm{~Pb},{ }^{210} \mathrm{~Pb}$ and ${ }^{7} \mathrm{Be}$ in the Outdoor Atmosphere. Natural Radiation Environment VI, Montreal, Canada, 5-9 June, 1995, Book of Abstracts, p. 199, Clarkson University, Potsdam, NY.

Röbig, G., Becker, K.H., Hessin, A., Porstendörfer, J. and Scheibel, H.G. (1980).

A Cascade Impactor Calibration for Measurements of Activity Size Distributions in the Atmosphere. Proc. $8^{\text {th }}$ Conference in Aerosol Science, p. 96-102, Georg-August University, Gottingen, Germany.

Shapiro, M.H. and Forbes-Resha, J.L. (1976). Mean Residence Time of ${ }^{7}$ Be-bearing Aerosols in the Troposphere. J. Geophys. Res. 81: 2647-2649.

UNSCEAR (2000). Sources and Effects of Ionizing Radiation. United Nations Scietific Committee on the Effects of Atomic Radiation, Vol. I, United Nations, New York.

Winkler, R., Dietl, F., Frank, G. and Tschiersch, J. (1978). Temporal Variation of ${ }^{7} \mathrm{Be}$ and ${ }^{210} \mathrm{~Pb}$ Size Distribution in Ambient Aerosol. Atmos. Environ. 32: 983991.

Young, J.A., Tanner, T.M., Thomas, C.W., Wogman, N.A. and Petersen, M.R. (1975). Concentrations and Rates of Removal of Contaminants from the Atmosphere in and Downwind of St. Louis Pacific Northwest Laboratory. Annual Report for 1974 to the USAEC Division of Biomedical and Environmental Research, Part 3, Atmospheric Sciences, p. 70-76.

Young, J.A. and Silker, W.B. (1980). Aerosol Deposition Velocities on the Pacific and Atlantic Oceans, Calculated from ${ }^{7} \mathrm{Be}$ Measurements. Earth Planet. Sci. Lett. 50: 92-104.

Yu, K.N. and Lee, L.Y.L. (2002). Measurements of Atmospheric ${ }^{7} \mathrm{Be}$ Properties Using High-efficiency Gamma Spectroscopy. Appl. Radiat. Isot. 57: 941946.

Received for review, November 19, 2008 Accepted, January 5, 2009 